ADALAH : Buletin Hukum \& Keadilan

\title{
Perlindungan Hukum Terhadap Tenaga Kerja Indonesia
}

\author{
Siti Nurhalimah*
}

\section{Fenomena}

banyaknya

pengangguran tak henti menjadi pembahasan negara, karena menjadi tugas pemerintah untuk menyediakan lebih banyak lapangan pekerjaan, demi memenuhi hak konstitusional warga negara sesuai dengan amanat ayat 2 pasal 28D UUD 1945 yang menyatakan bahwa "setiap orang berhak untuk bekerja serta mendapat imbalan dan perlakuan yang adil dan layak dalam hubungan kerja."

Program

penempatan

Tenaga Kerja Indonesia ke luar negri merupakan salah satu upaya pemerintah untuk menanggulangi masalah pengangguran di Indonesia yang kian membeludak. Sebagaimana termuat dalam data Badan Pusat Statistik yang menyatakan bahwa tingkat pengangguran di Indonesia mencapai angka $6,32 \%$ yaitu 7,61 juta orang pada februari 2012 (Muin, 2014: 12).

Penempatan Tenaga Kerja Indonesia bermanfaat untuk mengurangi tumpukan pengangguran, dan juga dapat meningkatkan kesejahteraan keluarga melalui gaji yang diterima atau remitansi. Selain itu, dapat meningkatkan keterampilan TKI, karena mereka akan mendapat pengalaman kerja. Bagi negara, manfaat yang diterima berupa peningkatan penerimaan devisa, karena para TKI yang bekerja tentu memperoleh imbalan dalam bentuk

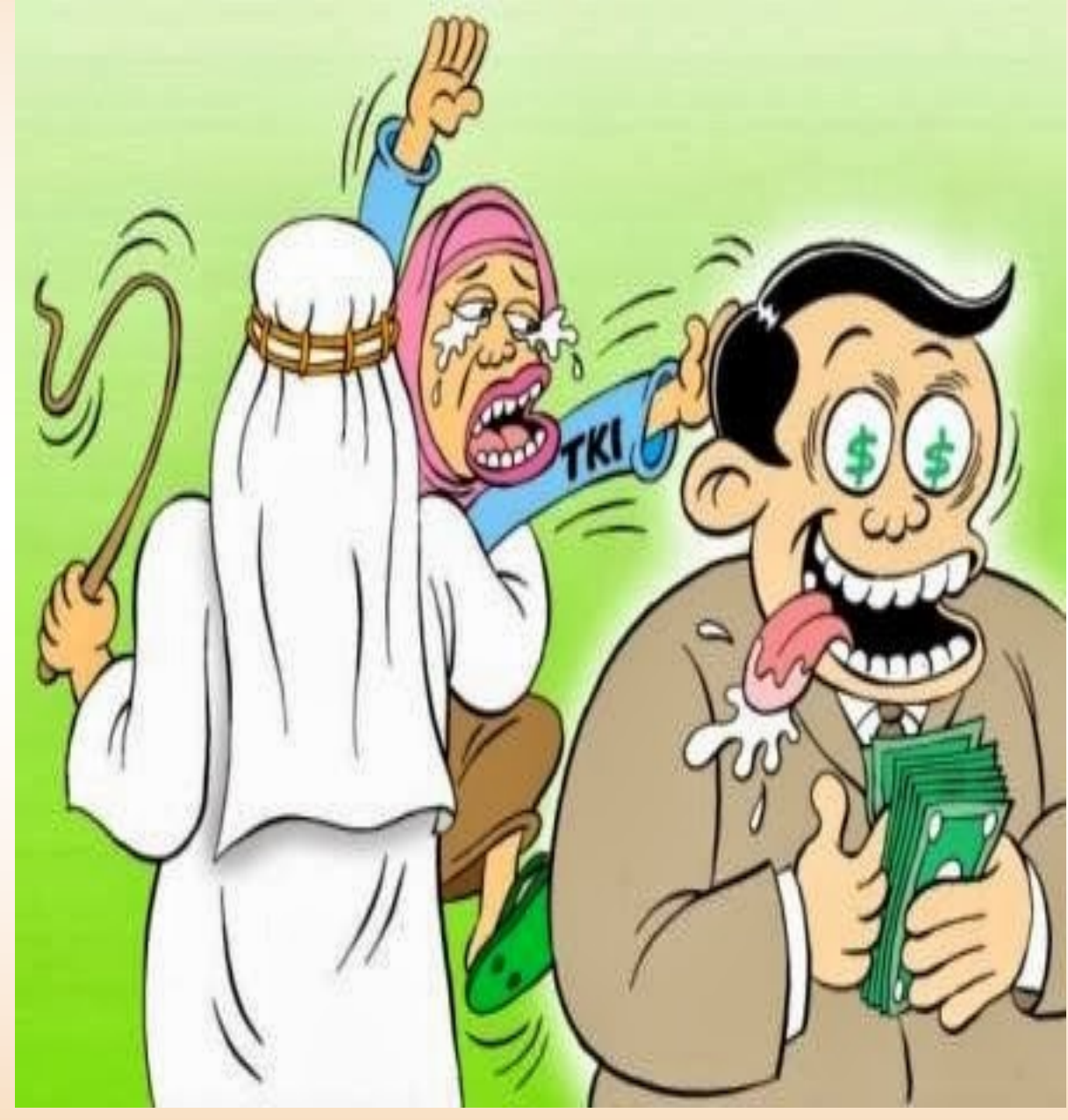

valuta asing.

Pada tahun 2015 Badan Nasional Penempatan dan Perlindungan Tenaga Kerja Indonesia (BNPTKI) melampirkan data bahwa, remitansi Tenaga Kerja Indonesia menyumbang devisa negara sampai USD 10,5 miliar atau Rp 144,95 triliun (kurs Rp 13. 805 per USD).

Akan tetapi sisi negatif dari pengiriman Tenaga Kerja Indonesia ke luar negeri juga sangat banyak. Terlihat dari banyaknya tindak kekerasan yang terjadi pada TKI, human trafficking terhadap tenaga kerja wanita, tersangkutnya TKI pada kasus-kasus hukum, hingga tidak dibayarnya gaji TKI selama bekerja. Semua permasalahan tersebut menjadi problematika ketenagakerjaan berkepanjangan yang tak kunjung usai.

Hal ini dibuktikan oleh data 
yang dilansir Migrant Care bahwa jumlah kasus kekerasan terhadap Tenaga Kerja Indonesia menduduki posisi tertinggi, bahkan di Malaysia saja mencapai 39\% (Muin, 2014: 22).

Tingginya tindak kekerasan yang terjadi pada TKI tidak dapat lagi dianggap main-main. Hal ini patut menjadi sirine bagi pemerintah Indonesia untuk meningkatkan perlindungan terhadap TKI yang ditempatkan di luar negeri. Karena dengan disahkannya Undang-Undang Nomor 39 tahun 2004 tentang Perlindungan dan Penempatan Tenaga Kerja Indonesia di Luar Negeri, telah sangat jelas bahwa hal ini menjadi tanggung jawab serta kewajiban pemerintah demi terpenuhinya hak TKI untuk mendapat perlindungan dan terbebas dari segala jenis tindak kekerasan.

Patut disadari bahwa sudah sejak lama pembahasan mengenai perlindungan warga negara tak kunjung surut dipermasalahkan. Sebagaimana yang diungkapkan oleh Andi Muhammad Asrun dalam jurnal cita hukum bahwa (Asrun, 2016: 152):

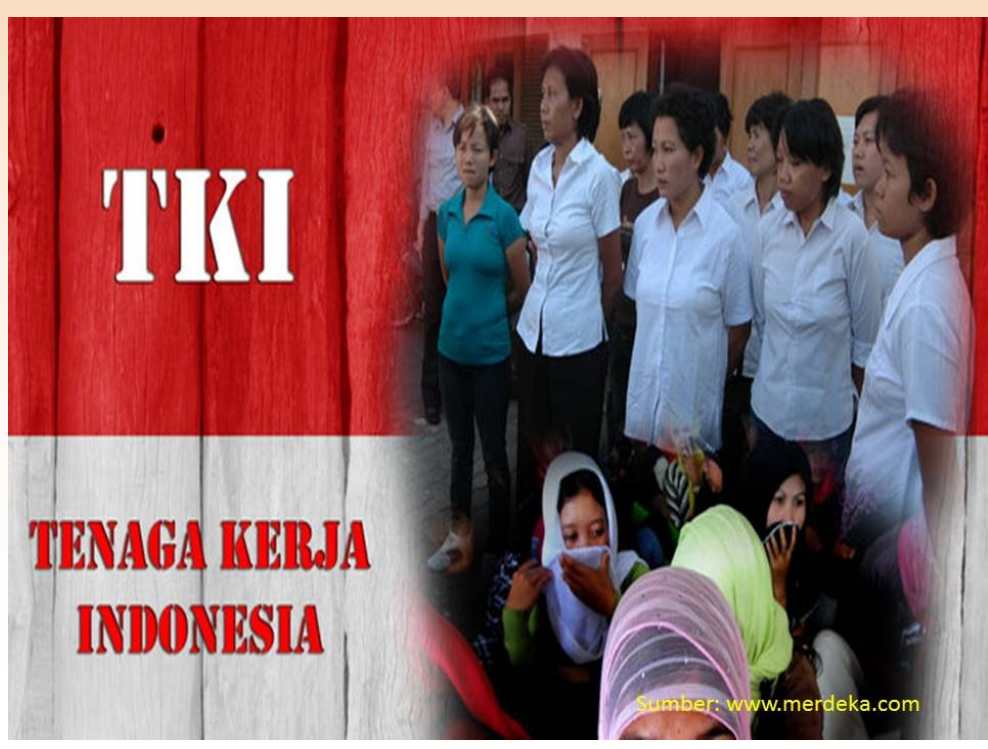

wujud amandemen Pasal 28 UUD 1945, menjadi pasal $28,28 \mathrm{~A}, 28 \mathrm{~B}, 28 \mathrm{C}, 28 \mathrm{D}, 28 \mathrm{E}, 28 \mathrm{~F}, 28 \mathrm{G}, 28 \mathrm{I}$, dan 28J tentang hak asasi manusia, tetapi wujud konkrit terhadap perlindungan warga negara yang bekerja di luar negeri belumlah terealisasi dengan baik.

Tingginya jumlah kekerasan terhadap TKI yang kian bertambah setiap tahun, mengisyaratkan bahwa segala regulasi mengenai hak warga negara, baik yang digariskan dalam UUD 1945, undang-undang tentang Hak Asasi Manusia, bahkan undang-undang tentang Perlindungan Tenaga Kerja Indonesia yang dianggap dapat mengakomodir pemenuhan hak warga, nyatanya tidak dapat menjamin perlindungan hukum bagi warga negara khususnya yang bekerja di luar negeri guna mendapatkan hak konstitusionilnya.

Oleh karena itu, langkah utama yang perlu dilakukan pemerintah adalah mengoptimalkan peraturan perundangundangan yang ada, dengan terus melakukan pengawasan terhadap perusahaan-perusahaan penyedia jasa Tenaga Kerja Indonesia, serta mengedukasi para calon tenaga kerja yang akan

"Perlindungan hak warga negara telah menjadi pembicaraan serius sejak persiapan kemerdekaan Indonesia, yaitu ketika para bapak bangsa mendiskusikan untuk memasukkan aturan perlindungan hak asasi ke dalam UUD 1945, dengan dua pandangan ekstrim. Pertama Sukarno yang kemudian menjadi Presiden pertama Republik Indonesia -- dan guru besar ilmu hukum Profesor Soepomo menolak memasukan soal Hak Asasi Manusia ke dalam UUD 1945, karena menurut mereka negara sebagai "kepala keluarga" bagi rakyatnya pastilah memberikan perlindungan kepada warganya tanpa harus ada aturan perlindungan warga negara di dalam konstitusi. Kedua, Mohammad Hatta - yang kemudian menjadi wakil presiden -- dan professor Mohammad Yamin berpendapat penting memasukan perlindungan hak warga negara ke dalam konstitusi supaya ada kepastian hukum. Perlindungan hak warga negara mencapai momentum ketika diadakan amandemen UUD 1945.

Meski kemudian, gagasan perlindungan warga negara dalam konstitusi dapat terealisasikan dalam ditempatkan di luar negeri, sehingga tenaga kerja yang dikirim merupakan Tenaga Kerja Indonesia yang terampil dan berbakat.[]

\section{Daftar Pustaka:}

*Penulis adalah anggota Perhimpunan Mahasiswa Hukum Indonesia (PERMAHI) dan Anggota Moot Court Community (MCC) FSH UIN Jakarta.

Asrun, Andi Muhammad. 2016. Hak Asasi Manusia Dalam Kerangka Negara Hukum: Catatan Perjuangan di Mahkamah Konstitusi, Jurnal Cita Hukum, Vol. 4, No. 1, Desember.

Muin, Fatkhul. 2015. Perlindungan Hukum Terhadap Tenaga Kerja Indonesia (Tinjauan Terhadap UU Nomor 39 Tahun 2004 Tentang Penempatan dan Perlindungan Tenaga Kerja Indonesia), Jurnal Cita Hukum, Vol. 3, No. 1, Juni.

'Adalah; Buletin Hukum dan Keadilan merupakan berkala ilmiah yang diterbitkan oleh Pusat Studi Konstitusi dan Legislasi Nasional (POSKO-LEGNAS), Fakultas Syariah dan Hukum UIN Syarif Hidayatullah Jakarta.

Penasehat: Prof. Dr. H. Abdul Ghani Abdullah, SH., Prof. Dr. H. A Salman Maggalatung, SH., MH. Pemimpin Redaktur: Indra Rahmatullah, Tim Redaktur: Nur Rohim Yunus, Fathuddin, Mara Sutan Rambe, Muhammad Ishar Helmi, Erwin Hikmatiar. Penyunting: Indah Furba, Hasin Abdullah. Setting \& Layout: Siti Anisaul Kamilah. 